\section{REMARKS ON THE LATE TRIAL}

BETWEEN

The College of Physicians and Dr. Har. rison.

\section{To the Editor of The LANCET.}

Sin,-The protracted contest, raised by the Fellows of the College of Physicians, having at length terminated in their complete defeat, after two hearings in court, and at an expense to them for my taxed costs alone of 781 . 12s., I am desirous, through the medium of your valuable Journal, to communicate some particulars connected with that celebrated struggle.

1st. I may premise, that the late trial records the first failure, since the enactment of their present by-laws. It has established the important fact, that they are not only illegal, but what is scarcely to be credited, that their validity can only be successfully opposed by the Fellows themselves, i. e., by the very men who framed them to secure an exclusive benefit, and now defend them for aelfish and unworthy purposes. From persons of this description, no correction of abuses will voluntarily proceed. They have taken a false position, and, favoured by legal quibbles and fictions, can maintain it, in defiance of every opposition, before the ordinary tribunals.

What is done for the improvement or credit of the repudiated physicians, must be achieved by themselves. This is really the fact, and I shall not attempt either to dis. guise it, or to mislead the public. The College was originally seized, and is still illegally held, by a dominant faction, to the exclusion of all others. Such has been the - relative state of parties, from about the year 17.5\% to the present moment, and they will, I am persuaded, remain as they now are, until the injured persons can be induced to unite their energies, and collectively prosecute their claims before Parliament; then they will be triumphant. As the sacred cause affects more or less every physician in the British dominions, notling more seems to he required, than a good beginning and a respectable association.

gdly. Whoever will give himself the trouble to look carefully into the charter of Henry VIII. will find, that it provides, 1 st, for the extinction of ruacks; 2d, for the searching of drug shops ; Sd, the licensing of surgeons, apothecaries, and menmidwives, or of all persons who, from not having been examined, and admitted to practise by some university, require to have their fitness approved in another way. These being trusts of great moment and interest to society, Henry confided their execution generally to the dactors of medicine resi. dent within the city of London. In order to carry his intentions into effect, he established the College of Physicians, "after the example of well regulated cities in Italy, and many other countries." But the Colleges of Physicians abroad, it is noto rious, were all composed of doctors in me. dicine, and no others; consequently, the College of London, instituted after their ex. ample, must have been similarly constituted. The original members of the London Col. lege, I therefore conclude, both from the language of the charter and the reason of the thing, consisted solely of doctors in physio of various universities; these were the " bomines facultatis" of the charter, an expression which has been so much misunder. stood and misrepresented. These were the members, and the only members, of the London College.

Henry entrusted the execution of the charter, in the first instance, to six graduates of Italian universities. Not one of them had either studied, or been entered, of either Oxford or Cambridge; from which it is evident that these universities rere never intended by the royal founder to en. joy superior privileges. Such was the original constitution of the College, and so it remained, in fact, equally open to all physi. cians, until a faction narrowed the incorporation to promote their own views. This disgraceful occurrence, which diverted the College from its original purpose, took place, as already observed, about the middle of last century. From that period to the present time, the College has been involved in unceasing litigation, or turmoil, and its agitations will continue undiminished, so long as the rejected members are deprived of their constitutional rights. How long relief may be deferred, I know not. Come it certainly will, sooner or later, and this act of tardy justice would be accelerated, if the injured could be induced to forego their petty jealousies, and exert their combined eneryies to obtain substantial redress. Such a course would be manly and honourable: but so long as the influential licentiates will condescend to cringe and flatter the most insignificant fellows, to gain a seat in the conclave, they are unworthy of the freedom to whic $h$ they aspire.

3dly. It has been objected to the defence. that it was sufficiently at variance with the style and manner of the letters, to disap. point the just expectations of the profes. sion. That the pleadings were not in stict accordance with the correspondence, I ad. mit ; but, in making this concession, I may be al:owed to add, that circumstances, orer which I could exercise no control, and for which I am, therefore, not answerablt, 
obliged me to deviate into a tortuous track, after I had, as I believed, only to follow a straight path. During this fatiguing journey, I was left to pursue my route alone, neitber meeting with a solitary companion to lessen my toil, nor any one to offer me the smallest acconmodation. Of this inattention I never complained; but I may be now permitted to observe, in my own justifeation, that if, in traversing a hitherto unexplored region, I had the misfortune to lase $m y$ way, I am the only sufferer, and deny the right of any human being to cali me to account, even if he should be able to how that there has been some unintentional mismanagement of the adventure. Several gentlemen came forward during the contest to enlighten the public with their profound lucubrations on College affairs. As they were not, however, intended for my instruction or assistance, but to display their own learning and private wishes, I acknowledge no obligations to the writers. Some of these advocates, thinking only of themselves, said, in very coarse terms, that $I$ ought volunta. rily to have given up the verdict, for the purpose of arguing the (unimportant) points reserved by Lord Tenterden.

The accusations of those who censure me, are founded on my not persisting in a course ascertained to be impracticable. I have already remarked, that unexpected obstacles drove us to substitute a mode of defeoce which neither I nor my professional edviser originally contemplated. Under such circumstances, we of course took ad. vantage of opportunities in our favour as they arose. No fair or reasonable man would expect us to neglect any prudent and just measure to obtain a verdict. Sane persons, I might add, do not go into courts of law for the purpose of heing defeated. As the main questions which I originally con. sidered at issue, would not be suffered to be argued either in this or a new trial, it became necessary to substitute other modes of proceeding, and in these we were successful. Should it be asserted that no good will spring out of the trial; I do not hesitate, in the most unqualified manner, to deny the inference. The College claims being all founded on the charter of Henry VIII., and the constitution of that charter being now placed in a clear and incontrovertible light, plysicians will in future not be liable to be dectived, respecting the true foundation of their rights to praclise physic in London, 8nd to be admitted members of that corporation: and the information thus acquired, cannot fal soon to produce immense benefit to the public, and important and useful clanges in the medical profession. Ilence. forward no one will, as a maiter of course, acquiesce in the extravagant and injurious pretensions of the College, here denomi- nated to be both assumed and illegal. No doctor will, in future, become a licentiate of that body, but in compliance with the necessity imposed upon him, if he either is, or intends to be, a caudidate for the office of physicion to any hospital, dispensary, or other public institution, of which the by laws unjustiy and injurionsly require that their pliysicians should be fellows, candi. dates, or licentiates of the London College. In confirmation of this I may remark, that since the commencement of my contest with the College, they have been joined by fewer licentiates than formerly. Last year (from October 189\%, to October 1828,) they amounted only to eleven; this year they will probably be still less numerous; and but for the necessity imposed by the by-laws alluded to, it is my. firm conviction there would be none.

Were the authors of these charges fully aware of all the difficulties under which $I$ laboured, they would be little inclined either to blame my zeal or want of resolution. On my remoral to the metropolis, about ten years since, I was called several times into consultation with the late Dr. Baillie, as I had often been during my abode in Lincolnshire. He urged me, at every opportunity, to become a licentiate, adding, that as I was now resident in London, unless $I$ complied with the request, be could not, consistently with his obligations to the College, meet me as a pliysician.

With a view to fix my wavering determinaticn, and arrive at a satisfactory conclusion, I stated my difficulties to a gentleman of great legal experience and eminence; he soon removed them, by informing me, among other consolatory circumstances, that the Fellows could only sue by their modern name of " President and Fellows of the Royal Colleg'e of Physicians." 'That after having so long abandoned their proper title of c President and College, or Commonalty of the King's College of Physicians in the City of London," they could only recover it after proving their connexion with the statute 14 and 15 of Henry TIII. Moreover, that the reasonableness of every by-law, involving $\mathrm{my}$ interests as a physician, must be satisfactorily proved in court, before they could enforce penalties under it. Encouraged by a legal opinion, in strict accordance with the result of all former inquiries, I resolv-i sither to enter the College, according to the obvicus interpretation of the charter, and the only legal mode of admitting members, or to practise as an indepen. dent physician, regardless of the consequences. I came the more readily to this conclusion, because I felt confident, from the great respectability of the gentleman applied to, that a contention with the Col. lege would oblige tive fellows to expunge 
some of their by-laws, and, probably, to restore the charter, in all its purity, to the well-educated physician.

Relying upon this opinion, and without any ill humour towards the Fellows, I forwarded my letters to Dr. Chambers and the Censors.* They were all written under a confident assurance, that the College would be obliged to establish, by argument, their legal existence, the reasonableness of their by-laws, and several other difficult matters, before they could claim mulcts for practice. This conviction will, I trust, sufficiently justify the bold language in which my letters were endited. In this dubious situation matters remained some time, and when $I$ supposed the business finally concluded I received official notice that the action had commenced ; in a short time afterwards the fellows proceeded to " declare," or set forth, the objects of their suit.

Upon receiving the latter notification, I called a meeting of my junior counsel and solicitors; it was at this consultation, and not sooner, that I was made acquainted with my actual situation. I then learned, for the first time, the difficulties of my position, and that the College would not be called upon to defend their by-laws, and what was more mortifying still, that the judges would not suffer me to dispute their validity in a qui tam action. Mr. Campbell confirmed this doctrine at our last interview, only three days before the cause was decided. Upon receiving this information $I$ offered to surrender the verdict, if I should be suffered, on a second trial, or even in the House of Lords, to impugn the by-laws. Having re. ceived the assurance of both my counsel that I should gain nothing in a new trial, nor any good by a removal into the House of Lords, I left them to pursue their own course, and use their own discretion, in managing the suit. Had I suspected Miss Orton's dissimulation and treachery before the cause came into court, I should have been prepared to controvert her insidions machinations, and defeat the College on the merits of my case.

During the long time that Miss Orton remained under my professional directions I possessed her entire confidence, as $I$ am prepared to show by her own letters; nor had she ever given me reason to doubt her high sense of honour, or strict adherence to the truth. She then resided in a very respectable family, where she had neither temptation nor example to encourage a different course. Why she left it abruptly to live secluded with a young medical bachelor forms no part of my present inquiry. After she had determined on removing, though the place of selection was carefully con-

* See former Numbers of The Lancet. cealed, I became justly alarmed, well know. ing the dangerous connexious she had form. ed. I therefore interrogated her strictly concerning the part she intended to act in my trial. She replied, that no prescriptions of hers should ever be turned against me. The following morning she repeated the same assurances, adding, with emotion and apparent sincerity, that 1 , who hoew her so well, should be the last to suspect her veracity. Having strong reasons for think. ing that she was under the management of needy and designing characters, I prevailed upon a mutual acquaintance to call, and ascertain, if possible, the temper of her mind, and her unreserved sentiments, with respect to me and the approaching trial. Her expressions, on this occasion also, being equally explicit and satisfactory, I unfortunately no longer doubted her veracity and good faith. To have hesitated, after such repeated assurances, to give full credit to the declarations of a lady who had never deceived me, would, I think, have shown both unbecoming scepticism and unjusti. fable distrust. With this impression strong* ly fixed in my mind, and which was, moreover, strengthened by a correspondence with her brother, Miss Orton removed to her new lodgings, and $I$ have never seen ler since.

I had remained some time in this delusory state of security, both as to Miss Orton and the trial, when, to my great surprise, the cause was unexpectedly taken, by some secret agency, out of its proper order, and set down for hearing on the following Thurs. day; the lawyers, on both sides, declarng their entire ignorance of the new arrange. ments, and of the hidden influence which produced it. Fortunately, the brief bad been already prepared, with great care and ability, by my solicitors; to it I afterwards subjoined not fewer than nine distinct propositions. My object in setting them down for argument was, to oblige the Fellows to defend the reasonableness of their by-laws, and the legality of their proceedings. The propositions were illustrated and supported with such reasons and deductions as occur. red to me at the exigence of the moment. Could the judge have been prevailed upon to suffer their discussion, I really believe that the College would have lost both its authority and its charter. However I may lament this determination, as the points themselves could not be argued, we were obliged to submit. That due paius were taken, on the part of my solicitors, to briug the case properly into court, will, I thick, be admitted, when I add, that the brief aloro filled thirty common sized folios, written in the usual manner. My own obserrations occupied eleven similar pages.

Such being the mode adopted in this strug* gle to obtain a full hearing of our grievances, 
I may confidently assert, that every care was taken, on my part, to conduct the aftair with proper circumspection, and with a view to its thorough investigation.

At length the day of trial arrived, and it was scarcely opened before $I$ discovered that, so far from my propositions being deliberately argued, not one of them would be suffered to occupy the court for a single minute. It was, on our side, a Parthian contest from the first to the last, in which we could not make a single halt, but were successively driven from post to post. After the last had been carried, and no place of refoge could be found, the combat was suspended. A long pause ensued, which was interrupted by a call for Miss Orton. The name no sooner vibrated on my ears, than I became fully alive to her duplicity and lypocrisy, but the knowledge came too late to admit of my attempting to rebut her evidence on the present occasion. Had I been defeated, a new trial would have enabled me to bring up fresh forces, and recover the victory. Happily the verdict renders it unnecessary for me to enter further in to the contest, and I feel no desire to retaliate upon an unprotected female, who once possessed my esteem, and has, I believe, forfeited it more through the artifices of others than her own inclination. No sooner did Miss Orton's well disciplined servant, Em. ma Edwards, stand up in the witness box, than Mr. Campbell, tapping me on the thoulder, said, "Is this a spinal case ?" I answered, "Yes." Not another word was exchanged between us during the remainder of the trial. The girl had a bundle of prescriptions put in to her hand; they were tied together at one end, leaving them loose, and waving below. This ingenious contrirance produced an imposing display, and gave the appearance of a much greater collection of prescriptions than she really possessed. They were written for three different females.

1st. Several of them were for the witness herself, who was forced, on cross-examination, to admit, that $I$ received no pecuniary remuneration from her. On this being conceded, the Judge ruled, that her case did not come within the meaning of the statute, or subject me to penalties for acting as a furcician, the very essence of which consists in accepting fees.

zdly. Mrs. Purser, a poor, infirm, and bet-ridden widow, afforded another exam. f.- of practice, brought against me in this wemorable trial ; she laboured under a compluation of maladies, aggravated by her comacted means; her prescriptions incased the bundle beld in the hand of Emma Fiwards, but it must have been known both torer and the plaintiffs that they were irre- levant, as they addèd nothing to my emolument.

3 dly. 'The plaintiffs had hunted out an. other instance of practice ; the object of it was actually subpoenaed, and brought into court, though they did not venture to place him in the witness-box, having discovered that his evidence would prejudice their cause. This youth, an under-waiter in Mr. Marshall Thompson's Hotel, applied for my gratuitous advice; he afterwards became the patient of two junior Fellows. These gentlemen having induced the boy to give up my prescriptions, lodged them, as I am told, in the archives of their College, to be in readiness to appear in due time against me. 4thly. Although I do not intend, at present, to scrutinise the conduct of Miss Orton, or the extraordinary evidence of her female servant, it was in my power to have completely destroyed the force of their united testimony, had it been suspected that this deceitful woman, and her well-tutored attendant, were to appear against me.

The Fellows, I am informed, complain bitterly of the heavy cost of the trial. How all their money was expended, does not appear. In the absence of direct proofs, we may be suffered to conjecture, that if Miss Orton was really endowed with greater for * titude than Danae, some of her partisans might not be equally insensible to the magic influence of a "golden shower."

These were some of the mean arts to which my learned opponents did not hesitate to stoop, in order to obtain the verdict, After this explanation, it would, I think, be more than superfluous to produce fresh proofs of the quo animo by which the governing members of the most ancient medical institution of the United Kingdom contrive to bolster up their affairs, and mislead the public. I have already said, that Mr. Campbell formed his successful appeal to the jury, ont of the expressive monosyllable "yes." He contended, 1st, That the spinal disorder under which Miss Orton suffered belongs to the surgical department, and that practitioners are not required, in the treatment of such maladies, to connect themselves with the College of Physicians. 2 dly, That before the Fellows could establish my liability to penalties under the statute, they must prove continuous practice for one whole month.

Mr. Campbell's eloquent address led to a verdict in my favour. It was certainly nei. ther so complete nor so satisfactory as I origi. nally expected. But as we were not suffered to grapple with the by-laws, it was perhaps the best that could be obtained, under the unexpected difficulties of our novel position. The conclusions arising out of the above premises are,

1st. That the "College or Commonalty 
of the Faculty of Physic," erroneously denominated the "Royal College of Physicians," was established for the equal benefit of all doctors of physic residing within its boundaries.

2 dly. That its members were indiscriminately taken from British and Foreign universities until the middle of last century, when a dominant party narrowed the admissions to graduates of Oxford and Cambridge.

Sdly. That since this illegal derivation and application of the honours and revenues of the College, it has been sensibly declining in usefulness, in respectability, and in power.

4thly. That, in the trial of Drs. Archer and Fothergill, also of Drs. Stanger and Cook with the College, the contest was with licentiates, or persons, who, having voluntarily engaged to obey the by-laws, could not afterwards get disengaged from them.

5thly. That, in the trial with Dr. Harrison, as the College sued only for penalties stated in the charter, the wholesomeness of the by-laws could not be brought under re. view, otherwise the defendant was prepared to show their illegality, their oppression, and their mischievous effects upon medical science and the faculty.

6thly. That the clause under which Dr. Harrison was prosecuted was not applicable to him, because it refers only to those medical men, who having procured no degree or nuthority to exercise medicine from an university, are therefore required in the charter to be examined and licensed to practise by the College of Physicians.

Will the Fellows condescend to inform the public, why this delegated power was applied to Dr. Harrison, a regular graduate, an homo facultatis, instead of being enforced against the persons for whom it was really enacted? The Fellows are requested, while giving their explanation, to bear in mind Lord Tenterden's recommendation to the jury in this particular trial: "It is our duty here to administer the law, and if the law be wrong, it is the Legislature which must correct it, and not you or 1."

7 thly. That it follows, as a consequence of the preceding trials, that neither the licentiates, nor the independent physicians, can obtain redress in the courts of law, merely because they are not members of the corporation, and that relief, when it is obtained, must be procured through the interference of parliament.

Thongh $T$ have already drawn largely upon the reader's patience, I am desirous to add to the above, the cogent observations of two other chief justices.

"The law is not wrong, the fault is in its administration.
In 1768 , the Fellows were cautioned by Lord Mansfield “ against narrowing their grounds of admission so much, that if eren a Boerhaave should be resident here, be could not be admitted into the fellowslip." Again : "I should recommend it to the College to take the best advice in reviering their statutes, and to attend to the design and intention of the crown and pariiament in their institution. I see a source of great dispute and litigation in them, as they now stand; there lias not, as it should seem, been due consideration had of their charter, or legal advice taken in forming them. I think that every person of proper education, requisite learning and skill, and possessed of all other due qualifications, is entitled to have a license; and I think that he ought, if he desires it, to be admitted into the $\mathrm{Col}$. lege." And again: "They are bound to admit every person whom, upon examina. tion, they think to be fit to be admitted within the description of the charter and act of parliament which confirms it. The per. son who comes within that description has a right to be admitted into the fellowship."

In 1797, Lord Kenyon says- "By what fatality it is that almost ever since this charter has been granted, this learned body bas somehow or other lived in a course of litigation, I know not; one is rather sur: prised, when one considers, that the several members of this body, including the licen. tiates, the commonalty of this corporation, are very learned men, and inasmuch as it is not generally the fruits of learning, at least not the best fruits of learning, to get into litigation, one cannot well tell, how these learned gentlemen have fallen into so much litigation."

With these remarks and quotations, which might have been considerably extended, I take leave of the College. I can with truth declare at parting, that I do not entertain the slightest feeling of hostility or prejudice towards any of the Fellows, notwithstanding the altered behaviour of some of them to. wards me since the late decision in Tiest. minster Hall. If they could be induced to listen to any advice of mine, I would entreat them, in the spirit of peace, to follow the recommendations of Lord Mansfield, and re. store the charter of Henry, their only source of power, to its original purity. By com. plying with his salutary admonitions, thes will exalt the reputation of their College, promote their own respectability, and restore harmony to a distracted profession.

$$
\begin{aligned}
& \text { I am, Sir, Sc., } \\
& \text { EDWARD IJARRISis. }
\end{aligned}
$$

Holles Street, Cavendish Square, June 1\%, 1829. 